\title{
RESISTENSI INSULIN TERKAIT OBESITAS: MEKANISME ENDOKRIN DAN INTRINSIK SEL
}

\author{
(Obesity Related Insulin Resistance: Endocrine and Cell Intrinsic Mechanism)
}

\author{
Mira Dewi ${ }^{1}$
}

\begin{abstract}
The number of obese individuals worldwide has reached 2.1 billion and this will lead to explosion of obesity-related morbidity and mortality. Obese individuals will develop resistance to celluler action of insulin. The obesity related insulin resistance is the major risk factor of cardiovascular diseases and Type 2 Diabetes Mellitus, the disease which number has reached epidemic proportion. The association between obesity and insulin resistance seem to be cause and effect relation because studies on human and animal has indicated that the increase or decrease of body weight correlates with insulin sensitivity. Among of many mechanisms proposed, the most of ten proposed mechanisms are endocrine and cell intrinsik mechanism. The increase of fatty acid plasma concentration, dysregulation of adipokines and ectopic fat storage are proposed to be the endocrin mechanism that lead to obesity related insulin resistance while oxidative stress and mitochondria dysfunction are the cell intrinsic mechanisms that play role to the disease. Understanding the molecular mechanisms of obesity related insulin resistance will provide valuable information to search for interventions that help to prevent or treat Type 2 Diabetes Mellitus and cardiovascular diseases and its related pathologies.
\end{abstract}

Keywords: Obesity, insulin resistance, fatty acid, adipokines, oxidative stress, mitochondria

\section{PENDAHULUAN}

Jumlah penderita obesitas di seluruh dunia telah mencapai 2.1 milyar dan hal ini pada gilirannya akan berakibat pada meledaknya masalah kesehatan dan kematian terkait obesitas (Olshansky 2005 dalam Qatanani, 2007). Obesitas merupakan suatu keadaan di mana berat badan seseorang jauh melampaui berat badan standar berdasarkan tinggi badan (Mahan, 2004). Menurut standar indeks masa tubuh (IMT), seseorang dikatakan mengalami obesitas bila nilai IMT-nya lebih atau sama dengan 25.

Pada penderita obesitas akan berkembang resistensi terhadap aksi seluler insulin yang dikarakteristikkan oleh berkurangnya kemampuan insulin untuk menghambat pengeluaran glukosa dari hati dan kemampuannya untuk mendukung pengambilan glukosa pada lemak dan otot (Park, 2006). Resistensi insulin terkait obesitas adalah risiko utama untuk dan penyakit kardiovaskular dan diabetes melitus tipe2, penyakit yang jumlah penderitanya telah mencapai proporsi epidemik. Empat puluh satu juta penduduk AS menderita prediabetik dengan resistensi insulin, hipertensi dan dislipidemia yang menempatkan penderitanya

\footnotetext{
${ }^{1}$ Staf Pengajar Departemen Gizi Masyarakat, Fakultas Ekologi Manusia (FEMA), IPB.
}

pada risiko peningkatan mortalitas dan morbiditas kardiovaskular (American Diabetes Association diabetes statistics pada http:// www. diabetes.org/diabetes-statistics/ prevalence. jsp).

Kaitan antara obesitas dan resistensi insulin sepertinya adalah sebab-akibat karena studi pada manusia dan hewan mengindikasikan bahwa peningkatan atau penurunan berat badan berkorelasi erat dengan sensitivitas insulin (Urukawa, 2003). Pada tulisan ini akan diuraikan mengenai mekanisme yang menerangkan bagaimana peningkatan massa adiposa pada obesitas menjadi predisposisi untuk terjadinya resistensi insulin sistemik. Meskipun lebih banyak jalur mekanisme telah diajukan berkaitan dengan hal tersebut, berikut hanya akan diuraikan mengenai dua mekanisme yang paling banyak diajukan, yakni mekanisme endokrin dan intrinsik sel.

\section{MEKANISME ENDOKRIN}

\section{Peningkatan Konsentrasi Asam lemak Plasma}

Dahulu, asam lemak yang disekresi dari sel-sel lemak (adiposit) dianggap hanya berfungsi sebagai sumber energi untuk kebutuhan jaringan tubuh lainnya. Pemikiran bahwa asam lemak ini berfungsi sebagai faktor endokrin yang mengatur fungsi metabolik pertama kali 
diajukan >40 tahun lalu ketika Randle dkk. pada 1963 berhipotesis bahwa terjadinya resistensi insulin terkait obesitas hanya dapat dijelaskan oleh adanya kompetisi antara kadar asam lemak yang meningkat dalam sirkulasi dan glukosa untuk metabolisme oksidatif pada sel-sel yang responsif terhadap insulin.

Setelah makan atau infusi lipid, konsentrasi asam lemak plasma meningkat dan asam lemak lalu ditransport ke dalam sel B melalui protein pengikat asam lemak (fatty acidbinding protein). Di dalam sitosol, asam lemak diubah menjadi turunan asam lemak koA, yang pada gilirannya mengganggu sekresi insulin melalui berbagai mekanisme : 1) peningkatan pembentukan asam fosfatidat dan diasilgliserol yang baik secara langsung atau tidak langsung menyebabkan eksositosis dari insulin yang disimpan dalam granul sekretorik, 2) perangsangan $\mathrm{Ca}^{2+}$-ATP retikulum endoplasma yang mengakibatkan peningkatan konsentrasi kalsium intraseluler dan penguatan sekresi insulin, dan 3) penutupan kanal $\mathrm{K}^{+}$-ATP yang menghasilkan depolarisasi dari membran sel $B$, yang menyebabkan peningkatan kalsium intraseluler dan perangsangan eksositosis dari granul yang mengandung insulin (Bays, 2002; Kantartzis, 2006; Park, 2006).

Hiperglikemia yang terjadi setelah makan akan meningkatkan konsentrasi malonil koA di dalam sel B. Malonil ko A menghambat karnitin palmitoil transferase-1, dan mengganggu transport asil koA lemak ke dalam mitokondria di mana ia akan dioksidasi melalui siklus Krebs. Peningkatan asil koA lemak di sitosol bekerja sejalan dengan keadaan hiperglikemia untuk memperkuat sekresi insulin. Konsisten dengan observasi in vitro ini, peningkatan konsentrasi asam lemak plasma jangka pendek (2 sampai 6 jam) diketahui meningkatkan sekresi insulin pada rodensia dan manusia, dan sebaliknya, penurunan akutnya akan menghambat sekresi insulin yang distimulasi oleh glukosa.

Berbeda dengan efek akut dari peningkatan asam lemak yang merangsang sekresi insulin, paparan dalam waktu yang lebih lama ( $\geq 48$ jam) menyebabkan gangguan dalam respon sel B terhadap glukosa, baik in vitro mau pun in vivo pada hewan dan manusia. Efek penghambatan asam lemak plasma yang meningkat secara kronis tampak lebih nyata pada individu dengan predisposisi genetis terhadap diabetes melitus tipe 2 . Sebaliknya, penurunan konsentrasi asam lemak pada penderita diabetes tipe 2 memperbaiki sekresi insulin.
Unger mengemukakan istilah lipotoksisitas untuk menggambarkan efek penghilangan (deleterious effect) dari peningkatan kronis kadar asam lemak terhadap sekresi insulin oleh sel B pankreas. Pada tikus Zucker yang gemuk dan diabetes, peningkatan kronis kadar asam lemak plasma mula-mula akan mengakibatkan gangguan fisiologis dari sekresi insulin. Seiring dengan waktu, apoptosis sel $B$ terjadi dan massa sel $B$ akan berkurang sampai lebih dari $50 \%$. Di dalam sel $B$, peningkatan asil koA lemak akan meningkatkan pembentukan seramide. Seramide, pada gilirannya, akan memperkuat pembentukan oksida nitrat yang bersifat mematikan bagi sel B (Unger, 2000).

Pada sel yang menggunakan glukosa sebagai sumber energi, adalah pengambilan glukosa, bukannya metabolisme glukosa intraseluler, yang telah diimplikasikan sebagai langkah yang rate-limiting untuk terjadinya resistensi insulin yang diinduksi asam lemak (Shulman 2000). Pada model ini, asam lemak dan beberapa metabolit lain termasuk asil koA, seramid dan diasil gliserol (DAG) bertindak sebagai molekul sinyaling yang mengaktifkan protein kinase seperti PKC, Jun Kinase(JNK) dan penghambat faktor nuklear $B$ (NFB) kinase (IKK). Kinase-kinase ini dapat merusak sinyaling insulin dengan meningkatkan fosforilasi serin yang bersifat inhibisi dari insulin receptor substrate (IRS), suatu mediator kunci dari sinyaling reseptor insulin.

Lepas dari mekanisme apa yang terjadi, peningkatan kronis fisiologis dari konsentrasi asam lemak plasma (478-666 $\mu \mathrm{mol} /$ liter) pada manusia non diabetes telah terbukti merusak sekresi insulin (Bays, 2002).

\section{Disregulasi Adipokin}

Adiposit mensekresi protein yang aktif secara metabolik. Penemuan leptin oleh Friedman dkk pada 1994 (Zhang et al. 1994 dalam Qatanani, 2007) mengawali era penerimaan bahwa jaringan adiposa adalah organ endokrin, dan bahwa peningkatan massa adiposa pada obesitas dapat menyebabkan perubahan patologis pada hormon adiposit (adipokin) yang mengatur sensitivitas insulin.

Adiponektin merupakan adipokin yang memiliki sifat insulinomimetik. Hormon ini dikarakteristikkan pada 1995 dan 1996 oleh 4 kelompok ilmuwan menggunakan metode yang berlainan. Kadar adiponektin ditemukan rendah pada obesitas, dan pemberian adiponektin memperbaiki keadaan resistensi insulin pada model hewan (Diez \& Iglesias 2003). Tikus yang kekurangan adiponektin akan menderita into- 
leransi prematur glukosa yang diinduksi diet dan resistensi insulin, dan mengalami peningkatan asam lemak serum (Maeda et al., 2002). Sebaliknya, overekspresi transgenik adiponektin pada tikus menyebabkan perbaikan sensitivitas insulin, toleransi glukosa dan penurunan kadar asam lemak serum. Di hati, adiponektin meningkatkan sensitivitas insulin, menurunkan influks asam lemak, meningkatkan oksidasi asam lemak dan mengurangi output glukosa hepatik (Bays, 2002). Di otot, adiponektin merangsang penggunaan glukosa dan oksidasi asam lemak mungkin dengan aktivasi sensor bahan bakar seluler, AMP-activated protein kinase (AMPK) (de la Maza MP, 2006).

Resistin diidentifikasi pada 2001 sebagai protein yang secara spesifik disekresi oleh adiposit yang ekspresinya di down-regulated oleh Thiazolidinedion, obat antidiabet dengan target reseptor inti PPARy (peroxisome proliferator activated receptor $\mathrm{y}$ ) (Ehtesham, 2001). Beberapa studi menunjukkan bahwa peningkatan ekspresi resistin dan kadarnya dalam serum berkaitan dengan obesitas dan resistensi insulin. Resistin serum ditemukan meningkat pada rodensia dengan obesitas, dan infusi atau ekspresi yang tetap terjaga dari resistin menyebabkan resistensi insulin. Sebaliknya, tikus yang kekurangan resistin memiliki homeostasis glukosa yang baik (Banerjee et al., 2004). Peran resistin pada manusia belum jelas. Bila resistin tikus secara eksklusif diekspresikan di jaringan adiposa putih, pada manusia resistin terutama diekspresikan di dalam se mononuklear yang bersirkulasi (Patel et al., 2003).

PAl-1 (plasminogen activator inhibitor-1) adalah anggota famili inhibitor protease serin dan merupakan penghambat utama fibrinolisis dengan menginaktifkan aktivator plasminogen tipe jaringan. PAl-1 diekspresikan oleh adiposit seperti halnya sel vaskular stromal pada depot adiposa. Kadar PAl-1 plasma meningkat pada obesitas dan resistensi insulin dan menjadi prediktor risiko DM tipe2 di masa depan. Tikus dengan delesi tertarget PAI-1 mengalami penurunan perolehan berat badan pada diet tinggi lemak, peningkatan pemakaian energi, perbaikan toleransi glukosa dan sensitifitas insulin yang baik.

Interleukin-6 (IL-6) adalah sitokin yang terkait erat dengan obesitas dan resistensi insulin. Pemberian perifer IL-6 menginduksi hiperlipidemia, hiperglikemia, dan resistensi insulin pada roden dan manusia. IL-6 merusak sinyaling insulin sebagian dengan downregulasi dari IRS dan upregulasi SOCS-3 (Kantartzis, 2006).
Tumor necrosis factor a (TNF a) adalah sitokin yang awalnya digambarkan sebagai faktor yang diinduksi endotoksin. TNF a adalah sitokin pertama yang diimplikasikan pada patogenesis obesitas dan resistensi insulin. Ekspresi jaringan adiposa dari TNF a meningkat pada roden dan manusia obes dan secara positif berkorelasi dengan adiposit dan resistensi insulin. Pemaparan kronis terhadap TNF a menginduksi resistensi insulin baik in vitro mau pun in vivo. Penatalaksanaan dengan reseptor TNF a solubel yang menetralkan memperbaiki sensitivitas insulin pada roden obes (Cheung et al. 1998). Pada manusia, kadar TNF a yang bersirkulasi meningkat pada individu nondiabetik obes dan DM tipe2, akan tetapi korelasi antara resistensi insulin dan kadar TNF a plasma relatif lemah (Miyazaki et al., 2003).

Adipokin yang terbaru yang muncul sebagai kontributor pada resistensi insulin yang diinduksi obesitas adalah retinol-binding protein 4 (RBP4). RBP4 diidentifikasi sebagai adipokin yang ekspresinya meningkat pada jaringan adiposa tikus dengan resistensi insulin dengan inaktivasi spesifik adiposa dari transporter glukosa GLUT4 (Yang et al. 2005). RBP4 diekspresikan tinggi di hati sebagaimana di jaringan adiposa, dan kadarnya dalam sirkulasi berkorelasi dengan obesitas dan resistensi insulin pada roden (Yang et al. 2005). Diduga, peningkatan kadar RBP4 serum berkontribusi terhadap resistensi insulin dengan merusak uptake glukosa yang distimulasi insulin pada otot dan meningkatkan produksi glukosa hepatik, walaupun mekanismenya belum sepenuhnya dimengerti (Yang et al., 2005).

Sebagai tambahan, adipositas viseral adalah karakteristik dari orang-orang dengan distribusi lemak bentuk apel, yang tampaknya memiliki risiko yang lebih besar untuk terjadi resistensi insulin daripada yang distribusi lemaknya berbentuk buah pir (Bjorntorp et al., 1991). Teori portal mengatakan bahwa resistensi insulin pada hati timbul dari drainase lemak viseral langsung ke hati via vena portal (Bergman et al., 2007). Perbedaan molekular lainnya antara lemak viseral dan perifer juga berperan dalam resistensi insulin dan berkaitan dengan adipositas viseral (Bergman et al., 2007).

\section{MEKANISME INTRINSIK SEL}

\section{Penyimpanan lemak ektopik}

Secara kronis, peningkatan asam lemak dalam sirkulasi dan lemak lain yang terjadi 
pada keadaan obesitas mengakibatkan penyimpanan lemak ektopik seperti trigliserida pada otot dan hati. Akumulasi lemak ektopik dilaporkan terjadi pada resistensi insulin (Unger \& Orci, 2000) secara potensial karena turnover trigliserida dan produksi molekul sinyaling turunan asam lemak, atau pengaktifan dari jalur intraselular yang berbahaya seperti Reactive Oxygen Species (ROS), disfungsi mitokondrial, atau cekaman retikulum endoplasmik.

\section{Stres Oksidatif}

Stres oksidatif sistemik yang didefinisikan sebagai ketidakseimbangan persisten antara produksi spesies molekuler yang sangat reaktif (terutama oksigen dan nitrogen) dan pertahanan antioksidan, berhubungan dengan akumulasi lemak pada manusia dan tikus (Dobrian et al., 2001; Furukawa et al., 2004). Hipotesis bahwa stres oksidatif adalah faktor penyebab dalam berkembangnya resistensi insulin didukung oleh beberapa studi yang menunjukkan bahwa ketidakseimbangan antara ROS dan antioksidan dapat memperbaiki resistensi insulin pada tikus dan manusia (Furukawa et al., 2004). Banyak studi pada manusia dilakukan terhadap hubungan antara stres oksidatif dan resistensi insulin berfokus pada pembentukan ROS oleh hiperglikemia pada pasien diabetes, mengimplikasikan ROS sebagai konsekuensi dari hiperglikemia yang diinduksi DM dan bukan faktor penyebab untuk terjadinya resistensi insulin (Urukawa et al., 2003). Akan tetapi, karena resistensi insulin telah terjadi sebelum berkembangnya hiperglikemia kronis, sepertinya resistensi insulin pada tingkat prediabetik bukan akibat dari stres oksidatif yang dipicu oleh hiperglikemia saja (Bays, 2002). Peningkatan ROS dalam tahap prediabetik tampaknya lebih karena peningkatan asam lemak terkait obesitas yang menyebabkan stres oksidatif karena peningkatan uncoupling mitokondrial dan oksidasi $B$, menyebabkan peningkatan produksi ROS (Fariss et al. 2005).

In vitro, ROS dan stres oksidatif mengarah pada pengaktifan kaskade sinyaling kinase serin/treonin multipel (Park et al., 2006). Kinase yang telah diaktifkan ini tidak dapat beraksi pada sejumlah target potensial dalam jalur sinyaling insulin, termasuk reseptor insulin dan famili protein IRS (Insulin Receptor Substrate). Untuk IRS 1 dan IRS 2, peningkatan fosforilasi serin menurunkan jangkauan pengaktifan fosforilasi tirosin. Kinase-kinase yang diaktifkan oleh stres oksidatif termasuk JNK, p38 MAPK, dan IKK (Qatanani et al., 2007).

\section{Disfungsi mitokondria}

Resistensi insulin dan DM tipe2 berhubungan dengan penurunan fungsi mitokondria yang ikut berperan dalam terbentuknya akumulasi lemak ektopik di otot dan lemak (Shulman, 2000). Perubahan-perubahan ini diikuti dengan penurunan aktivitas oksidatif mitokondria dan sintesis ATP mitokondria, yang keduanya merupakan indikasi penurunan fungsi mitokondria. Penurunan serupa dalam aktivitas mitokondrial dan peningkatan isi lemak intramioseluler juga ditemukan pada anak-anak muda dengan resistensi insulin yang orang tuanya menderita DM tipe2. Kelompok ini memiliki kecenderungan kuat untuk menderita DM tipe2 nantinya (Fariss et al., 2005).

Subjek dengan resistensi insulin diduga memiliki akumulasi lemak intramioseluler yang lebih banyak karena penurunan jumlah mitokondria otot yang disebabkan oleh penurunan ekspresi gen yang mengatur biogenesis mitokondria, seperti PPARY co activator 1 a (PGC-1 a ). Diduga, resistensi insulin pada manusia mungkin muncul akibat defek pada fungsi mitokondria, yang pada gilirannya akan meningkatkan metabolit asam lemak intraselular (asil ko A lemak dan DAG) yang mengganggu sinyaling insulin pada otot dan hati. Di lain pihak, fungsi mitokondria dibutuhkan untuk terjadinya peningkatan ROS yang diinduksi asam lemak (Dobrian et al. 2001). Penjelasan akan hal ini adalah bahwa bisa jadi peningkatan ROS yang disebabkan oksidasi asam lemak terjadi lebih awal selama perkembangan resistensi insulin dan sebanding dengan disfungsi mitokondria. Pada tahap yang lebih lanjut, ROS dapat menyebabkan penurunan fungsi mitokondria yang akibatnya adalah akumulasi lemak pada otot dan hati, dan dengan demikian membangkitkan fenotipe resistensi insulin.

\section{KESIMPULAN}

Resistensi insulin terkait obesitas adalah kelainan yang kompleks yang melibatkan berbagai jalur mekanisme. Kemajuan dalam penelitian biologi molekuler telah membuat terobosan besar dalam menemukan banyak hal berkaitan dengan resistensi insulin dibanding sepuluh tahun lalu. Banyak jalur mekanisme yang secara simultan terganggu, dan ketika satu jalur terganggu, interkoneksinya dengan jalur lain akan mengakibatkan perubahan pada sistem lain. Mekanisme yang terjadi terkait dengan banyak jalur dan mediator-mediator 
yang juga terlibat dalam berbagai penyakit serius termasuk kanker dan kelainan autoimun.

Pemahaman detail dari tiap sistem dan bagaimana sistem-sistem ini terkait satu sama lain pada manusia akan memberikan dasar bagi pencarian akan intervensi yang dapat memperbaiki keadaan ini, tidak hanya yang terkait dengan DM tipe 2 dan penyakit kardiovaskular, tetapi juga penyakit-penyakit yang memiliki jalur yang terkait dengan keadaan yang mendasari resistensi insulin seperti kanker dan kelainan autoimun.

\section{DAFTAR PUSTAKA}

American Diabetes Association diabetes statistics. http://www.diabetes.org/diabetes-statistics /prevalence.jsp).

Banerjee RR, Rangwala SM, Shapiro JS, Rich AS, Rhoades B, Qi Y, Wang J, Rajala MW, Pocai A, \& Scherer PE. 2004. Regulation of fasted blood glucose by resistin. Science, (303), 1195-1198.

Bays, 2002. Role of the Adipocyte, Free Fatty Acids, and Ectopic Fat in Pathogenesis of Type 2 Diabetes Mellitus: Peroxisomal Proliferator-Activated Receptor Agonists Provide a Rational Therapeutic Approach. Journal of Endocrinology, 6(7), $75-80$

Bergman RN, Kim SP, Hsu IR, Catalano KJ, Chiu JD, Kabir M, Richey JM, \& Ader M. 2007. Abdominal obesity: Role in the pathophysiology of metabolic disease and cardiovascular risk. Am J Med, 120 (1), S3-S8.

Bjorntorp $P .1991$.Metabolic implications of body fat distribution. Diabetes Care, 14 (14),1132-1143.

Cheung A, Ree D, Kolls JK, Fuselier J, Coy D, Bryer-Ash M. 1998. An in Vivo Model for Elucidation of the Mechanism of Tumor Necrosis Factor- $\boldsymbol{\alpha}$ (TNF- $\boldsymbol{\alpha}$ )-Induced Insulin Resistance: Evidence for Differential Regulation of Insulin Signaling by TNF- $\boldsymbol{\alpha}$ Endocrinology, 139(12),4928-4935

de la Maza MP. 2006. Weight increase and overweight are associated with DNA oxidative damage in skeletal muscle. Clin Nutr, 25(6),968-76.
Diez JJ \& Iglesias P. 2003. The role of the novel adipocyte derived hormone adiponectin in human disease. Eur $\mathrm{J}$ Endocrinol, (148),293-300.

Dobrian AD. 2001. Oxidative Stress in a Rat Model of Obesity-Induced Hypertension. Hypertension, 37(554).

Ehtesham NZ. 2001. Molecular link between diabetes and obesity: The resistin story. Current Science, 80(11),34-37.

Fariss MW. 2005. Role Of Mitochondria In Toxic Oxidative Stress. Molecular Interventions 5,94-111.

Furukawa S. 2004. Increased oxidative stress in obesity and its impact on metabolic syndrome. J Clin Invest, (114),1752-1761

Kantartzis K. 2006. The Relationships of Plasma Adiponectin with a Favorable Lipid Profile, Decreased Inflammation, and Less Ectopic Fat Accumulation Depend on Adiposity. Clinical Chemistry, (52), 1934-1942

Maeda N, Shimomura I, Kishida K, Nishizawa H, Matsuda M, Nagaretani $H$, Furuyama N, Kondo H, Takahashi M, \& Arita Y. 2002. Diet-induced insulin resistance in mice lacking adiponectin/ACRP30. Nat Med, 8, 731-737.

Mahan K \& Stump S. 2004. Krause's Food, Nutrition and Diet Therapy. Saunders, 565569.

Miyazaki Y, Pipek R, Mandarino LJ, \& DeFronzo RA. 2003. Tumor necrosis factor and insulin resistance in obese type 2 diabetic patients. Int J Obes Relat Metab Disord, (27), 88-94.

Park J. 2006. Increase in Glucose-6-Phosphate Dehydrogenase in Adipocytes Stimulates Oxidative Stress and Inflammatory Signals. Diabetes, (55),2939-2949.

Patel L, Buckels AC, Kinghorn IJ, Murdock PR, Holbrook JD, Plumpton $\mathrm{C}$, Macphee $\mathrm{CH}$, \& Smith SA. 2003. Resistin is expressed in human macrophages and directly regulated by PPAR activators. Biochem Biophys Res Commun, (300),472-476.

Qatanani M. 2007. Mechanisms of obesity-associated insulin resistance: many choices 
on the menu. Genes \& Dev. (21),14431455

Randle PJ, Garland PB, Hales CN, \& Newsholme EA.1963. The glucose fattyacid cycle. Its role in insulin sensitivity and the metabolic disturbances of diabetes mellitus. Lancet, (1),785-789

Shulman GI. 2000. Cellular mechanisms of insulin resistance. J Clin Invest, (106), 171-176.

Unger RH \& Orci L. 2000. Lipotoxic diseases of nonadipose tissues in obesity. Int J Obes Relat Metab Disord, 24(4),S28-S32
Urakawa H. 2003. Oxidative Stress Is Associated with Adiposity and Insulin Resistance in Men. The Journal of Clinical Endocrinology \& Metabolism, 10(88), 4673-4676

Yang Q, Graham TE, Mody N, Preitner F, Peroni OD, Zabolotny JM, Kotani K, Quadro L, \& Kahn BB. 2005. Serum retinol binding protein 4 contributes to insulin resistance in obesity and type 2 diabetes. Nature, (436),356-362. 